\title{
The Western Canadiana Publications Project at the University of Alberta
}

\author{
N. Parker-Jervis
}

I HAVE BEEN ASKED TO TALK TO YOU ABOUT THE WESTERN CANADIANA publications project, about its creation, its plans, and what I expect will engage this group most, its bibliographical interests. The main objective of the series is to publish significant works to do with Western Canada in reliable editions so as to preserve, bring forward, and enliven the traditions of the region.

This is how the WCPP began. As early as I970 I organized a petition from this University to the National Library urging it to produce under its auspices a Canadiana reprint programme. Subsequently groups from other universities endorsed the petition, but the National Library declined to undertake the task, except that in 1974 it did agree, with help from the Devonian Foundation, to reproduce in microform all the titles in Bruce Peel's Bibliography of the Prairie Provinces to 1953. I think this idea may have been a model for another project which I read about in University Affairs for May 1978. There it was reported that the Canada Council was to fund the Canadian Institute for Historical Microreproduction with a \$2 million grant to reproduce in microform Canadiana published before I900. The announcement stated that the collection would relate closely to published bibliographies - on the Peel model, I take it. I am reminded also that the Symons Report on Canadian studies said that 'bibliographies are indispensable tools of scholarship' (p. 39). Bibliographers know that, we know that, but do funding agencies?

In I975, in my slow way, I thought of another approach since the first had not succeeded. I thought that the University of Alberta might try to get a major editorial grant from the Canada Council for a programme of publishing Western Canadiana in both original and reprint forms. The Library, the University of Alberta Press, and members of various departments were all interested in this idea, and we formed, inevitably, a committee. That was in October I975. Our first task was groundwork to excite interest in the project and to build up evidence of need. We sent out questionnaires to every Canadianist we could think of, asking what work they would like to see done. We got a considerable response - I43 replies, 204 reprint titles and 62 original titles suggested, and 64 offers to edit; certainly enough to demonstrate anew 
that scholars in the field perceived a considerable need for Western Canadiana. The Symons Report came out about that time, and both its data and its conclusions strongly reinforced our position.

We also formed an Advisory Board whose members were distributed amongst the universities of Western Canada, were learned in our field, and had weighty names we could drop on funding agencies; people such as Bruce Peel, Henry Kreisel, and George Woodcock.

Once we had built up some momentum of response and interest, we sought official footing in the University. Through the advice and good offices of the Vice-President Academic, Dr. Horowitz, we became in February 1976 a President's Committee of the University of Alberta.

In May 1976 we wrote to the Canada Council saying that we intended to seek a major editorial grant for a general programme of Western Canadiana publications. The Canada Council asked for a fuller statement; this we sent in June 1976. That submission, by the way, included a most useful letter of support from Margaret Williams, then Chairman of the Committee on Bibliographical Services for Canada, and Peter Greig, its Secretary, had been one of the first to respond to our questionnaire.

The Canada Council realized we were serious and sent one of their negotiating officers to advise us. This officer, I expect deliberately to test the firmness of our purpose, made it very clear how onerous the whole process of application was. She also said that an application for a major editorial grant, in order to succeed, had to have 'a narrow and homogeneous corpus' and had to exercise one particular kind of scholarship.

Now it happened that our first general plan for Western Canadiana publication contained three focal areas, Riel and attendant circumstances, the roots of prairie fiction, and the documents and propaganda of settlement. We extracted the focus on Riel and made it the subject of an application for a grant to produce a definitive edition of the collected papers of Louis Riel. We chose Riel for several reasons: there was a defined corpus; the task exercised one particular kind of scholarship - historical; the subject was an important one, for Western Canada particularly; and we had at hand two noted Riel scholars, Dr. George Stanley and Dr. Thomas Flanagan, who had responded to our original questionnaire and were keen to work on Riel. We proposed to Drs. Stanley and Flanagan that they collaborate on a Riel project, and they agreed. With the valuable help of these scholars in putting together a team of Riel editors and in making the application, the WCPP began the arduous task of going after a major editorial grant. We eventually succeeded in April 1978 , just about two years after our first letter of intent.

The Riel project is expected to last more than five years, but apart from it, what has the WCPP done and what are its plans? We have not succeeded, though we have not given up trying, to raise funds for our general extensive 
publishing programme. The University of Alberta Press, by its own effort, has published several books that the WCPP was glad to see come into being; for example, L.H. Thomas' edition of Essays on Western History, Dick Harrison's Unnamed Country: The Struggle for a Canadian Prairie Fiction, and Frances Swyripa's Ukrainian Canadians: A Survey of their Portrayal in EnglishLanguage Works. We helped the Press raise money for one title, a reprint of Sandilands' 1913 Western Canadian Dictionary and Phrase Book. The University of Alberta Press also with the support of the wCpp has an application before the Canada Council for the translation of a most important work, Marcel Giraud's Le Métis canadien; we expect this application will succeed.

The University of Alberta Press also received this year from the Alberta Government's Heritage Publication Fund the sum of $\$ 50,000$ to be used in publishing works suitable to the Fund's purposes, that is, to publish Western Canadian educational materials for the school system. This Fund is an enormous one $-\$ 8.3$ million, no less, and since in some respects the purposes of the Fund and those of the WCPP are alike, we have good hopes that we can be helpful to each other.

Another activity of the WCPP is to publish a Newsletter twice a year, designed to be a service periodical, informative to those interested in Western Canadiana. It began in April 1978, and three issues have so far been published. I checked the three issues and noted that they contained twenty-one items on matters bibliographical and archival. In my opinion, that is where academic knowledge has to begin, in archives, in libraries, and in the bibliographies that list the sources of knowledge. I have already cited the Symons Report. Did you notice in it how insistently Dr. Symons calls for bibliographies in all subject areas? in the humanities alone some twenty times.

The WCPP is well aware of the importance of bibliographical work. Two members of our Advisory Board are noted bibliographers; Mr. Peel, of course, is one and Gordon Moyles is the other. Dr. Moyles is the author of an annotated bibliography entitled English Canadian Literature to 1900, published in the Gale Reference Series. Respondents to our questionnaire proposed six bibliographies: imaginative works related to Riel, ten major religious traditions present in Alberta, material related to the agricultural settlement of the Peace River area, anthropological articles from the Western Canadian Journal of Anthropology, an annotated checklist of book-length prairie fiction, and finally, as part of the work of the Riel project, a new complete bibliography.

But the bibliographical project most important to us is the bringing up to date of Bruce Peel's notable Bibliography of the Prairie Provinces to 1953. We have his permission, have begun the research, and plan to publish it in booklet form, probably as an adjunct to the Newsletter. I have saved to the last the best news about the neo-Peel bibliography, that it is in the capable hands of a professional bibliographer, Professor Gloria Strathern of our Library Science 
Faculty, well known to this audience as the compiler of one of the volumes in the three-volume bibliography of British Columbia published by the University of Victoria, and immediate Past President of the Canadian Association of Library Science Schools. She is present and will conclude our section of this meeting by telling you of some of the problems that need to be met in this bibliography, and, reservedly, of the bibliography as presently designed. In short, she will make a modest proposal - Professor Strathern. 